\title{
Integrated Information System Teaching Plan in College Using FAST Method and Twitter Bootstrap
}

\author{
Ika Ratna Indra Astutik ${ }^{\star 1}$, Mochamad Alfan Rosid ${ }^{2}$ \\ 1,2Universitas Muhammadiyah Sidoarjo \\ ikaratna@umsida.ac.id ${ }^{* 1}$, alfanrosid@umsida.ac.id²
}

\begin{abstract}
Teaching plan is one of the obligations that must be made by lecturer before conducting any lecture because teaching plan will be used by lecturer as a reference in determining Learning Outcomes (LO) and providing recovery materials in each semester. Unfortunately, there are still many existing teaching plans in College which are still manually developed. Thus, they may undermine head courses and Institute of Educational Development Study and Majors to perform learning monitoring and evaluation in the department. This research developes a system application which facilitates lecturer in managing teaching plan recovery and facilitates the Institute of Educational Development Study and Majors in evaluating the learning effectiveness, the suitability of the teaching journal and the achievement of Learning Outcomes. The system is developed using FAST method (Framework for the Application of System Thinking) and designed using a responsive Twitter Bootstrap template. The information generated system can also be used to support the cccreditation of Program Study. The testing process in this system uses blackbox testing to check the stability of the deployed system. The result of the test shows that all functions in the system runs perfectly, and the lecturers are more easily managing the Teaching plan, and the head of the Department can evaluate the suitability of the Teaching plan with teaching journal.
\end{abstract}

Keywords: Information System, Teaching Plan, Twitter Bootstrap, Blackbox Testing

\section{Introduction}

In improving the quality of learning, especially in the Colleges, it relies heavily on materials in delivering lectures. The materials which have been prepared properly can improve the quality of knowledge received by students. These teacher plans can be the reference for the lecturers in determining Learning Outcomes. In accordance with government regulations about the national standards of higher education year 2014 article 12 which states that teacher plan is the process of learning plans for each of the courses created by professors both individually or in group in one clump of expertise in science courses. The learning process is developed for each course by lecturer, organized in semesters. Teaching plans developed by lecturers independently or in groups in accordance with his knowledge of science, reviewed and adjusted periodically by the development of science and technology. Based on the provisions, lecturers are obliged to compile teaching plan prior to lectures which consists of learning product courses, the duration of students' acquisition process in meeting the product reference, types of learning method and the duration and level of assignments given to students. Courses are developed by lecturers in the set of study programs through the college curriculum in accordance with the applied scheduling.

There are some previous researches related to lecture's information systems discussing lecture's evaluation. Fachruddin on his research discussed Quality Assurance Agency in facilitating the head of study program in monitoring and evaluating the learning process conducted by lecturers in accordance with the standard specified by STIKOM Dinamika Bangsa Jambi including the manufacture of Lecture Events Unit [1]. Priyanto, et al., in his research, only discussed about the evaluation report per lecturer and an overall lecture evaluation report not proclaiming about teaching plan [2]. Noorhansyah, using the FAST method on the information system of business administration majors of customer relationship in State Polytechnic Banjarmasin, was able to process data and information to be more effective, efficient, timely and accurate [3]. Hendriyani also employed FAST method for designing the information system information in Hospital Service Remuneration. Moreoever, by utilizing the system, the quality of

Indra Astutik, I., \& Rosid, M. (2018). Integrated Information System Teaching plan (RPS) in College Using FAST Method and Twitter Bootstrap. Kinetik, 3(2). doi:http://dx.doi.org/10.22219/kinetik.v3i2.588

Receive November 16, 2017; Revise February 22, 2018; Accepted April 06, 2018 
information provided better results [4]. Rosid et al. implemented the framework Bootstrap Twitter to make the admission information system being responsive, lightweight and simple having the same interface if accessed in desktop and mobile mode [5].

The purpose of this research is to design a theaching plan to ease lecturers in developing teaching plan and facilitates educational development institution and study program in the evaluation of lectures related to the effectiveness of learning, the conformity of teaching plan with a existing journals of teaching and learning on its accomplishment to the learning outcome established by lecturers. Moreover, this system supports the needs of accredited study programs by providing features for accessing teaching plan entered into the system. The researcher utilizes system development method using Framework for the Application of System Thinking (FAST). The research object take on University of Muhammadiyah Sidoarjo (UMSIDA), having ongoing plan in the semester learning processes using Microsoft Word application with the format given by the university. Furthermore, the research objects take form of files saved in print for submission to the study program and educational development institutions. Due to their hard copy format, the authorized clerks faces in archiving the files of teaching plan when needed by the time the course or university's accreditation. The conventional method is by asking directly to the lecturers. Similarly, at the time of execution, the lectures providing non standard lecture material format making the learning outcomes not achieved.

\section{Research Method}

\subsection{System Design Method}

The design of the system in this research employs the FAST method in the system design consisting of initial investigation (study), analysis of the existing problems, analysis of the necessary system requirements, system design (interface) and system testing [6][7].The steps used in the design of the system are as folows:

1. Preliminary Investigation Phase

Preliminary investigation phase is required to design the system. Preliminary investigation infers issues in the plan preparation and the evaluation of the learning semester in the running academic year. These problems can be generated from systems in accordance with desired system to ease teaching plan management by lecturers, educational institutions and study programs.

2. Problem Analysis Phase

In this stage, the analysis of the problems is conducted to identify the existing issues and to formulate the desired system needs.

3. Requirement Analysis Phase

On this stage, the researcher analyze the required practices that need to be implemented by a teaching plan system and the users' needs and preferences, especially those directly related to the system.

4. Design Phase

The researcher, on this stage, develops the theaching plan information system in accordance with the analysis of the problems and analysis of the needs of users, lecturers, educational institutions and study program.

5. Implementation Phase

The established system will be run and testes to achieve conditions corresponding to the desired needs. This trial run of the system is conducted accompanied by the users, the system admin head of educational institutions and study program.

\subsection{System Design with Bootstrap Twitter}

The display design (interface) of the system uses Twitter Bootstrap supported by CSS and Javascript, which eases the developers to build interfaces for not only in website format but also in a web-based information system. Employing Bootstrap Twitter interface makes a sleek, responsive and intuitive system. It also offers flexibilities to be adjusted with required hardware to access the system such as Personal Computer (PC), tablets and smartphones.

The developers can quickly design a system or a website by utilizing Twitter Bootstrap with its front-end framework because it has already provided templates for CSS and Javascript functions supporting the creation of system. Those templates can be downloaded from the web already available as Bootstrap Twitter indicated in Figure 1.

KINETIK Vol. 3, No. 2, May 2018: 163-170 


\section{Built with Bootstrap.}

For even more sites built with Bootstrap, visit the unofficial Tumblr or browse the examples.
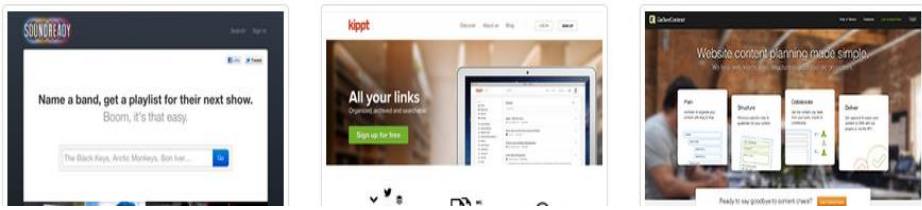

",

Figure 1. The Main Page of the Twitter Bootstrap Website

\section{Results and Discussion}

In designing the teaching plan information system using FAST method, it is conducted by the following stages:

\subsection{Preliminary Investigation Phase}

Initially, the researcher formulates problems in this research by collecting data and information from the informants and conducting direct observations from interviews and observations. The existing teaching plan system is now running on UMSIDA, a manual system, not yet computerized. The data and information are processed manually by using a word processing application and numbers, resulting less relevant generated information, resulting to timely decision-making process affecting the UMSIDA management.

\subsection{Problem Analysis Phase}

Identifying problems in recognizing the drawbacks to the existing system is conducted at this stage. From the results of the preliminary investigation, there are some weaknesses recognized grouped in PIECES (Performance, Economic, Information, Control, Efficiency and Service).

1. Performance

The data and information needed by UMSIDA management takes a long time because the creation and evaluation of the teaching plan are manually completed. The management needs to wait for file submission from the lecturers. With the new system, the presentation of data and information-based computer can be obtained quickly and optimally. The evaluation can be done directly after the lecturers enter data system in the teaching plan.

2. Information

Manual data construction process leads to less accurate and less complete information which negatively affect the evaluation and decision making process. Therefore, this information generated by the management does not comply with the actual information. In computerized generation information, the data can be collected in a fast, accurate and relevant manner.

3. Economics

The manual information generated method is proven to be economically ineffective due to the collection of teaching plans and reports in hardcopy format. In the new developed system, those data and information have already provided in the forms, being practically cost effective to UMSIDA management.

4. Control

Data processing and information regulations have not been optimally controlled due to its manually-developed nature. The existence of a computer-based system of teaching plan makes control function easier because each user has a username and password in accordance with the user's level in the system.

5. Efficiency

The duration need by UMSIDA management in conducting the evaluation still takes a long time and ineffective. A lot of teaching plans needed to be manually revised and corrected by the lecturers consume more time in the process decision-making information. 
By utilizing new system, these revision and correction functions can be conducted more effectively.

6. Service

Manual teaching plan system offers poor facilitation for the users in processing the data and information especially for lecturers and UMSIDA management. However, online teaching plan system offers significantly better system due to its capability to be accessed anytime and anywhere when needed.

Based on the prior problem identification, it is necessary that the teaching plan uses computer-based system and online which can effectively alter the information to help evaluation process of learning and lecture activities at UMSIDA.

\subsection{Requirement Analysis Phase}

Based on preliminary investigation and analysis of the problems, it can be concluded based on the analysis of information system that the teaching plan needs good functional and non functional needs. The results of the need analysis related to the system's functionality are presented in Table 1.

Table 1. System Functional Requirements

\begin{tabular}{llll}
\hline No & \multicolumn{1}{c}{ Users } & \multicolumn{1}{c}{ Information Requirements } \\
\hline 1 & Lecturers & a. Teaching plan data \\
& b. The evaluation results of the teaching plans \\
& C. Journal of teaching \\
& $\begin{array}{ll}\text { The Institution } \\
\text { of Educational }\end{array}$ & a. Access for the lecturer's teaching plan \\
& Development & c. Access validated teaching plans \\
& d. Report compliance of the teaching plan and teaching journal \\
3 & Study Program & a. Access data for the lecturer's teaching plan \\
& b. Print and download lecturer's teaching plan \\
& C. Report the evaluation results of the educational development \\
\hline
\end{tabular}

Client-server becomes the system's non-functional requirement, where the client accesses system information stored on the server computer using Linux operating system. Meanwhile, the software for the creation of information systems uses PHP (Hypertext Prepocessor) and PostgreSQL using data storage (database) which supports web-based information systems.

\subsection{Design Phase}

This stage covers the design of teaching plan information system in UMSIDA. The early stage of the design process is to determine the model information flow from system to users and information system. The data flow diagram becomes the most commonly used tool for information system analysis and design [8][9]. The model of information system is described with a data flow diagram (DFD) level 0 presented by Figure 2.

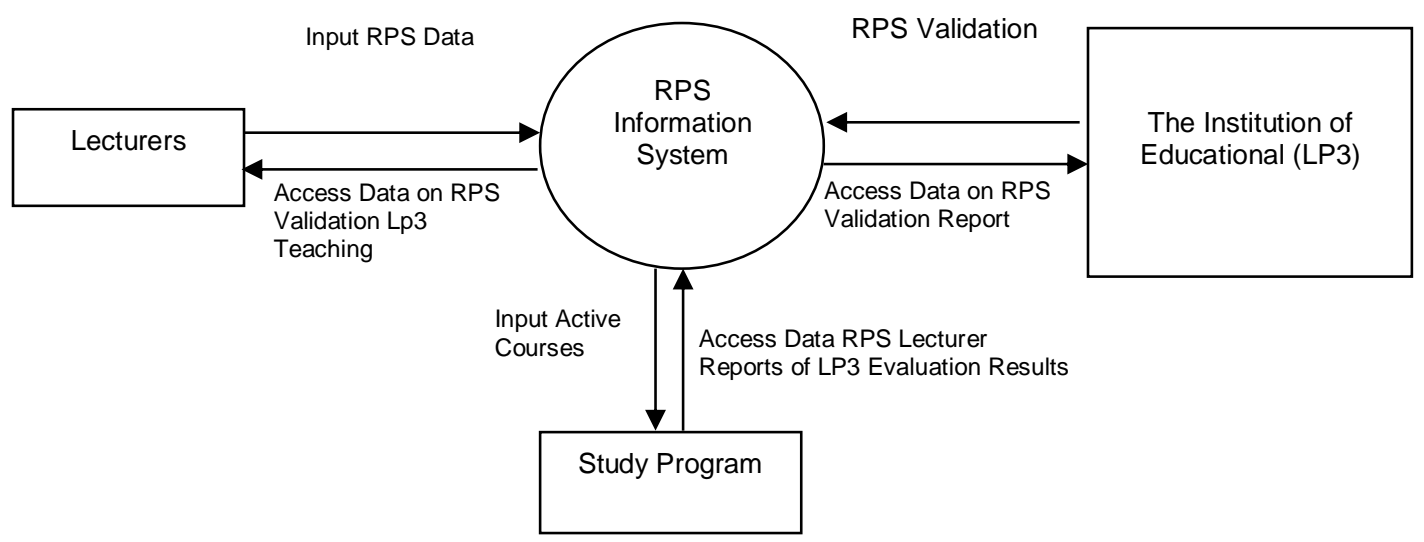

Figure 2. DFD Level 0 of Teaching Plan Information System

KINETIK Vol. 3, No. 2, May 2018: 163-170 


\subsection{Implementation Phase}

At this final stage, the program will be tested to meet with analysis and design. Afterwards, the new system will be implemented to be accessed by lecturers and UMSIDA management to perform testing to figure out the new system already as expected. Figure 3 presents the information system of lecturer's learning plan in case of any existing validation from LP3. hese lecturer's teaching journals alteratios can do that would affect the salary of a lecturer.
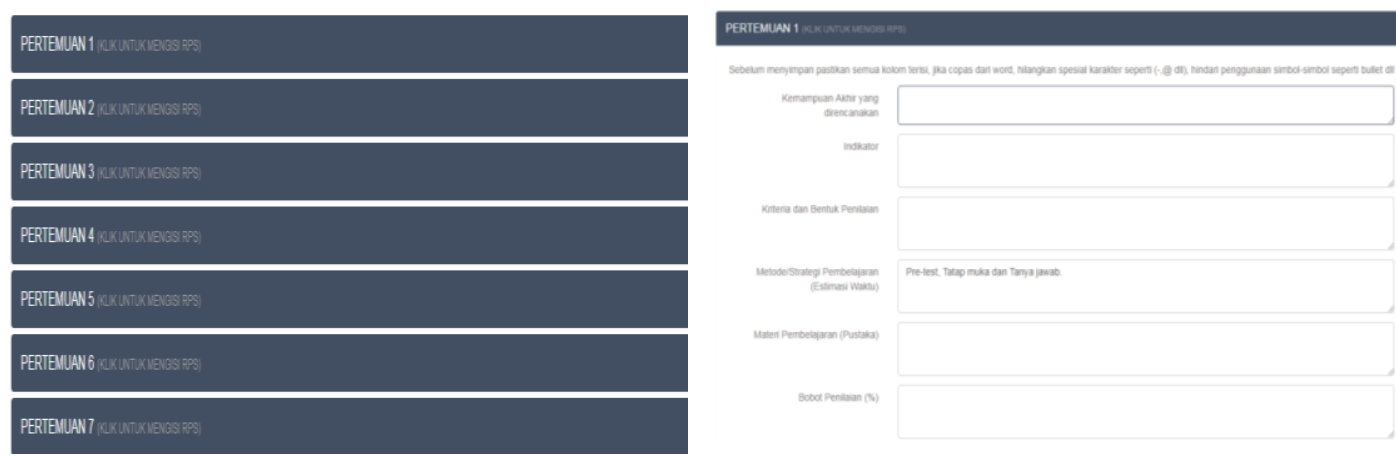

Figure 3. Teaching Plan Page Input for Lecturers

After lecturers input the data, LP3 will evaluate whether the teaching plan is in compliance or not by selecting the lecturer's name, the half dormant (odd or even) and the academic year as presented by Figure 4 .

\section{Data RPS Dosen}

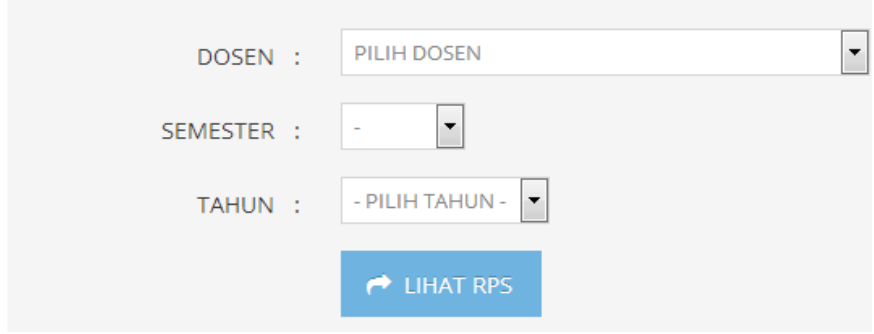

Figure 4. Data Page View of Lecturer's Teaching Plan in LP3IK

LP3 can push the designated button to display the teaching plan displaying a pop up list of subjects by the selected lecturer. It also displays courses taken from a predefined schedule by course of study in the running academic year. For study programs, the teaching plan can be displayed in the information system presenting courses in the teaching plan menu view. Afterwards, this chosen course of study and its active academic year is presented by Figure 5. In addition, there is a menu to print or download the teaching plan if necessary in the form of hard copy primarily upon accreditation.

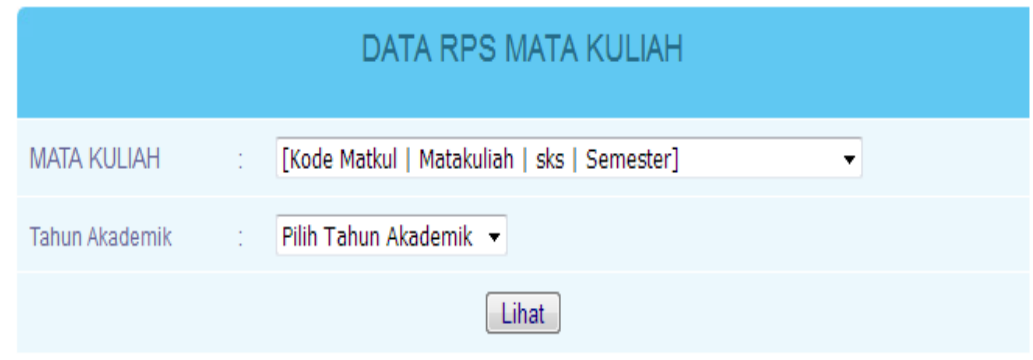

Figure 5. Page View of the Teaching Plan System Courses 


\subsection{Testing Phase}

Testing information systems using Black Box is used to find out whether the functions in the information system as a whole has been in accordance with the needs of the identified functional analysis [10]. The following test results of the information system by using Black Box are presented in Table 2.

Table 2. Test Results of the Information System Using Black Box

\begin{tabular}{|c|c|c|c|c|}
\hline No & Process & Fungsional Requirement & Expected Result & Actual Result \\
\hline \multirow{3}{*}{1} & \multirow{3}{*}{ Lecturers } & Teaching plan data & $\begin{array}{l}\text { User should be } \\
\text { able to see, input } \\
\text { and update the } \\
\text { teaching plan }\end{array}$ & $\begin{array}{l}\text { User is able to see, } \\
\text { input and update the } \\
\text { teaching plan data }\end{array}$ \\
\hline & & $\begin{array}{l}\text { The evaluation } \\
\text { results of the } \\
\text { teaching plan }\end{array}$ & $\begin{array}{l}\text { User should be } \\
\text { able to see the } \\
\text { evaluation results } \\
\text { of the teaching } \\
\text { plan }\end{array}$ & $\begin{array}{l}\text { User is able to see } \\
\text { the evaluation results } \\
\text { from the institution of } \\
\text { educational } \\
\text { development }\end{array}$ \\
\hline & & Teaching journal & $\begin{array}{l}\text { User should be } \\
\text { able to input and } \\
\text { delete the journal }\end{array}$ & $\begin{array}{l}\text { User is able to input } \\
\text { and delete the } \\
\text { journal }\end{array}$ \\
\hline \multirow{3}{*}{2} & \multirow{3}{*}{$\begin{array}{l}\text { The Institute of } \\
\text { Educational } \\
\text { Development }\end{array}$} & $\begin{array}{l}\text { a. Data view of the } \\
\text { teaching plan for } \\
\text { each lecturer }\end{array}$ & $\begin{array}{l}\text { User should be } \\
\text { able to see all } \\
\text { teaching plan }\end{array}$ & $\begin{array}{l}\text { User is able to see } \\
\text { all teaching plan }\end{array}$ \\
\hline & & $\begin{array}{l}\text { Display of validated } \\
\text { teaching plan }\end{array}$ & $\begin{array}{l}\text { User should be } \\
\text { able to validate } \\
\text { the teaching plan }\end{array}$ & $\begin{array}{l}\text { User is able to } \\
\text { validate the teaching } \\
\text { plan }\end{array}$ \\
\hline & & $\begin{array}{l}\text { Report compliance of } \\
\text { the teaching plan with } \\
\text { journal teaching }\end{array}$ & $\begin{array}{l}\text { User should be } \\
\text { able to make } \\
\text { compliance of } \\
\text { teaching plan } \\
\text { and journal }\end{array}$ & $\begin{array}{l}\text { User is able to make } \\
\text { compliance of the } \\
\text { teaching plan and } \\
\text { journal }\end{array}$ \\
\hline \multirow{3}{*}{3} & \multirow{3}{*}{ Study Program } & $\begin{array}{l}\text { a. Data view of } \\
\text { Teaching plan } \\
\text { lecturer }\end{array}$ & $\begin{array}{l}\text { User should be } \\
\text { able to see all } \\
\text { teaching plan } \\
\text { data }\end{array}$ & $\begin{array}{l}\text { User is able to see } \\
\text { all teaching plan }\end{array}$ \\
\hline & & $\begin{array}{l}\text { Print and download } \\
\text { the lecturer's } \\
\text { teaching plan }\end{array}$ & $\begin{array}{l}\text { User should be } \\
\text { able to print and } \\
\text { download } \\
\text { teaching plans } \\
\text { with excel format }\end{array}$ & $\begin{array}{l}\text { User is able to print } \\
\text { and download } \\
\text { teaching plans with } \\
\text { excel format }\end{array}$ \\
\hline & & $\begin{array}{l}\text { Reports of evaluation } \\
\text { result of the } \\
\text { educational } \\
\text { development }\end{array}$ & $\begin{array}{l}\text { User should be } \\
\text { able to see the } \\
\text { results of } \\
\text { evaluated } \\
\text { teaching plan } \\
\text { from educational } \\
\text { development }\end{array}$ & $\begin{array}{l}\text { User is able to see } \\
\text { the results of } \\
\text { evaluated teaching } \\
\text { plan } \\
\text { educational from } \\
\text { development }\end{array}$ \\
\hline
\end{tabular}

\section{Conclusion}

The teaching plan information system can facilitate lecturers in the teaching plan data processing. Moreover, it can also facilitate the reporting process of teaching plans to head of department and facilitate educational development institution of study program in evaluating the implementation of the decisions and lectures as well as supporting course accreditation requirements as well as the university. The teaching plan information system can also be accessed online and via a computer desktops, tablets or smartphones since the system is responsive, intuitive and fast. Lecturers, head department and educational development institution of the progam study can access system anywhere without having to go to the 
campus. Moreover, lecturer and head of department can access the data at any time by directly accessing in the information system.

\section{References}

[1] J. S. Informasi, "Information System of Monitoring dan Evaluating Study (A case Study: Stikom Dinamika Bangsa)," Vol. 8, No. 3, Pp. 45-57, 2014.

[2] W. Priyanto, D. Nugroho, and B. Widada, "System Information of Web-Based Course Monitoring in STMIK Sinar Nusantara Surakarta,"Pp. 53, 2003.

[3] M. Noorhansyah and A. Pratomo, "The Application of Customer Relationship Management Pada Metodologi Fast (A Case Study: The Development of Academic Portal on Faculty of Business Administration of State Polytechnic)," Vol. I, No. 2, Pp. 25-32, 2016.

[4] A. Hendryani, "System Information Remuneration Design on RSUD Kepahiang Service Bengkulu Using FAST Metode," Journal of Business System, Vol. 7, No. 1, Pp. 9, 2017.

[5] M. A. Rosid and R. B. Jakaria, "Implementation of Twitter Bootstrap Framework in the Design of Web-Based New College Student Admission," Kinetik, Vol. 1, No. ISSN : 25032259, pp. 129-134, 2016.

[6] R. Pressman, "Software Engineering: A Practioner's Approach 6th Edition." New York: McGrawHill, 2005.

[7] S. Mulyani, "Analysis and System Design Method," Bandung: Abdi Sistematika, 2016.

[8] H. Wang, Shouhong, and Wang, "Information Systems Analysis and Design," UniversalPublishers, 2012.

[9] V. Rajaraman, "Analysis and Design of Information System Third Edition," Asoke K Ghosh, 2011.

[10] A. Rouf, "Software Testing Using White Box dan Black Box Method," Journal Information Technology HIMSYA-Tech, Vol. 8, No. 1, Pp. 1-7, 2012. 
KINETIK Vol. 3, No. 2, May 2018: 163-170 